\title{
China's GDP: Some Corrections and the Way Forward
}

Peter M. Solar

Historical GDP estimates for China by Broadberry, Guan, and Li are problematic because of an implausible series for government expenditure. Revised estimates reduce GDP per capita, mainly during the Ming, by up to a third. Two peaks in income now stand out: the Song efflorescence and the years around 1700. If the latter peak is real, comparisons of the Yangzi delta with leading European countries show a Great Crossing in the Middle Ages, a Great Convergence in the seventeenth century, and a Great Divergence in the eighteenth. Otherwise, the Great Divergence may date from the sixteenth century.

B roadberry, Guan, and Li (2018; hereinafter BGL) have estimated China's GDP back to 980, farther back than any recent work on European economies. Although there are gaps, their decadal estimates cover large parts of the Song, Ming, and Qing dynasties. BGL argue that their work makes it clear that the Great Divergence in per capita incomes between northwest Europe and China dates from the early eighteenth century. Unfortunately, a serious error in their estimates for the government sector renders the estimates and the conclusions drawn from them invalid. This comment revises the government sector to produce more plausible GDP estimates and shows that divergence may date from much earlier. It also briefly assesses the nature and coverage of the data underlying BGL's estimates for other sectors and suggests an agenda for further research. Concerns about the quality of the data underlying estimates for other sectors will be left to the China specialists (see, e.g., Deng and O’Brien 2016).

The problem with BGL's government sector series is immediately evident when expressed either as government expenditure per capita

The Journal of Economic History, Vol. 81, No. 3 (September 2021). C The Economic History Association. All rights reserved. doi: 10.1017/S0022050721000309

Peter M. Solar is Professor, CEREC, Université Saint-Louis-Bruxelles, Boulevard du Jardin botanique 43, 1000 Brussels, Belgium, and Associate Member, Faculty of History, University of Oxford. E-mail: psolar@vub.ac.be.

I am particularly grateful to Jack Goldstone, Cormac Ó Gráda, and Kim Oosterlinck, who commented on several versions of this Note. Brian A'Hearn, Herman de Jong, Jane Humphries, James Kung, Debin Ma, Patrick O'Brien, and Shuo Chen also provided valuable advice, and Kent Deng, Bas van Leeuwen, and Ye Ma shared their knowledge of Chinese sources. As usual, the constructive criticism of the editor and referees of the Journal improved the comment. Thanks also go to the students in my world economic history course, as this comment grew out of discussing the article with them. 


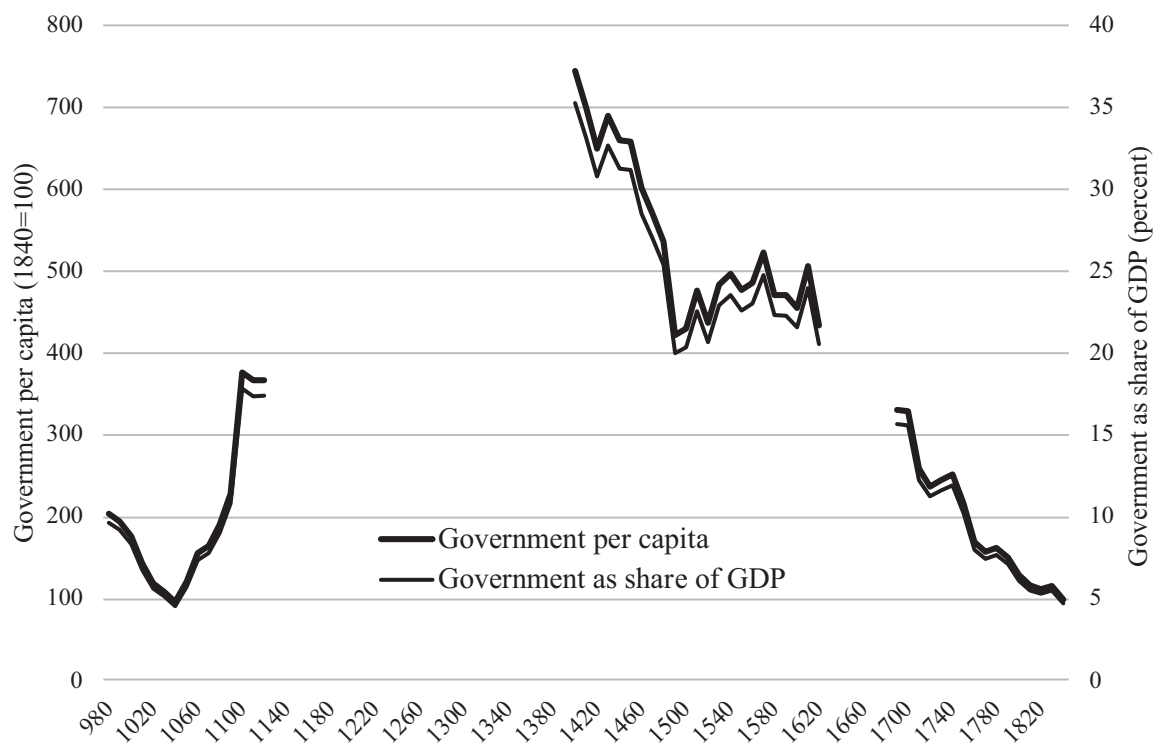

FIGURE 1

GOVERNMENT PER CAPITA AND AS A SHARE OF GDP

Notes: Steve Broadberry kindly supplied the indices that underlie the figures in the paper, which were not in the replication file.

Source: Broadberry, Guan, and Li (2018).

or as a share of their GDP estimates (Figure 1). Government spending per capita is more than seven times higher in the early Ming than in the mid-nineteenth century. The government share in GDP rises to over 35 percent in the early Ming and remains at more than 15 percent from the late Song to the early Qing. ${ }^{1}$ By the standard of pre-industrial economies, these shares are implausibly high. In Europe, peace-time government spending before the twentieth century rarely exceeded 10 percent (Prados de la Escosura 2007, p. 203; Bogart et al. 2010). In India, Broadberry, Custodis, and Gupta's (2015) estimates for the government share never exceed 2.7 percent between 1600 and 1840 .

BGL's shares for government expenditure are also inconsistent with evidence on government shares of expenditure or taxes in pre-industrial China. Deng (2012) reckons that under the Qing, the state may have controlled only some 8 percent of GDP, and Ma (2013) shows how the Qing state's revenue per capita was small by international standards. For the late sixteenth century, when BGL's government share is still over

\footnotetext{
${ }^{1}$ These are not strictly historical sectoral shares for want of information on changes in the price of government services relative to the prices of goods in other sectors. However, BGL's entire estimation strategy relies on relative values in 1840 .
} 


\section{China's GDP: Some Corrections and the Way Forward 945}

20 percent, Huang (1975, pp. 166-70) has calculated the share of the land tax in agricultural output as 6.7 percent in Hangzhou prefecture on the east coast and 5 percent in Fenzhou prefecture in the north. Since taxes on agriculture constituted the bulk of imperial revenue during the Ming (Wong 2012), these figures must mean that the overall tax burden could not have exceeded 10 percent. Some back-of-the-envelope calculations by Feuerwerker (1984) put the government share under the Song at a relatively high 13 percent, but only 6-8 percent under the Ming and 4-8 percent in the early Qing. These much smaller government shares underpin Rosenthal and Wong's (2011) argument that because China faced fewer military threats, the size of its government sector was always relatively small.

What may have gone wrong with BGL's estimates for the government sector? The estimates are based on numbers employed in the civil service and the military multiplied by their salaries, with the resulting figures for nominal expenditure deflated by the prices of grain and cloth. ${ }^{2}$ The military far outnumbered the civil service, with figures for the size of the army at the beginning of the Ming in the range of 1.3-1.8 million soldiers (Swope 2009). In a population of 70 million at the time, the adult male labor force would have been about 14 million, implying, at first pass, that the government share was no more than $10-15$ percent. ${ }^{3}$ For the government share of GDP to have been over 30 percent, average incomes in the public sector would have to have been at least two and a half times higher than in the rest of the economy. But soldiers were said to have been paid at the rate of day laborers (Robinson 2013), which suggests problems with either the salaries or the prices used by BGL.

A closer look at what soldiers did also raise the possibility of considerable double-counting in the early Ming and possibly in other periods as well. Much, if not most, of soldiers' time was spent growing their own food; others, perhaps as many as 100,000, were occupied in transporting grain by the Grand Canal (Robinson 2013). Military land accounted for 3-5 percent of all cultivated land in the early Qing and probably more during the Ming (Shi 2020, pp. 26, 44, 48). The estimates for agriculture and the transport of agricultural goods, both based on the cultivated land area and grain yields, incorporate no adjustment for such activity by the military. The numbers in the public sector may also have been inflated by

\footnotetext{
${ }^{2}$ Neither the underlying numbers for the military and the civil service nor their average salaries are provided in the replication file, so one can only speculate about the possible sources of error.

${ }^{3}$ These figures may overstate the size of the army, as they are usually based on the number of households required to supply troops. In the sixteenth century, the official registers showed three million hereditary soldiers, but contemporaries put the effective force at about 900,000 (Swope 2009, p. 19).
} 
the inclusion of corvée labor for handicraft production, which was prevalent particularly during the early Ming (Wen-Chin 1988). ${ }^{4}$ The estimates for industry, based as they are on population and urbanization, would not correct for changes in the extent of industrial activity within the government sector.

Does BGL's implausibly large government sector make a difference to our understanding of the pattern of economic change in pre-industrial China? Revised estimates can be made on three alternative assumptions about the government sector: (1) that it grew in line with population; (2) that its share of GDP remained constant over the entire period at its 1840 level; and (3) that its share of GDP followed Feuerwerker's rough estimates (Song, 13 percent; Ming, 7 percent; Qing, 6 percent). On the first assumption, the alternative estimate for GDP has been made by substituting BGL's index of population for their index of government expenditure and recalculating GDP using BGL's indices for other sectors. On the second and third assumptions, total output in the rest of the economy has been recalculated without BGL's government series, then these figures have been inflated by the assumed government share to arrive at alternative series for GDP.

Figure 2 shows the series for Chinese GDP per capita recalculated on these three assumptions and compares them to BGL's estimates (Solar 2021). The first thing to note is that the three assumptions give essentially the same results, except that during the Song when Feuerwerker's higher government share leads to higher per capita GDP and the populationbased series to lower per capita GDP. The second is that such assumptions sacrifice the temporal detail of annual, or even decadal, returns of government revenue or expenditure. The Chinese government's spending depended heavily on whether it had to fight off invaders, quell civil disturbances, or confront rival warlords (Ma 2013). But estimates based on such simple assumptions may be sufficient and more appropriate for long-run comparisons of peacetime national income.

When compared to BGL's estimates, the revised estimates leave the Song peak largely unchanged, except, again, where Feuerwerker's higher government share makes it even more pronounced. The major change occurs during the Ming, when the revised estimates are 25 percent lower early in the period, falling to about 15 percent lower in the late Ming. ${ }^{5}$

\footnotetext{
${ }^{4}$ See ongoing research by Zhang Zipeng on the craftsmen system during the Ming.

${ }^{5}$ Note that the difference between the revised and original estimates for GDP per capita is well outside the 5-15 percent margin of error indicated in BGL's reliability assessment; this is, even more, the case with the estimates for government expenditure. One might question whether such subjective assessments are themselves reliable indicators of accuracy.
} 


\section{China's GDP: Some Corrections and the Way Forward 947}

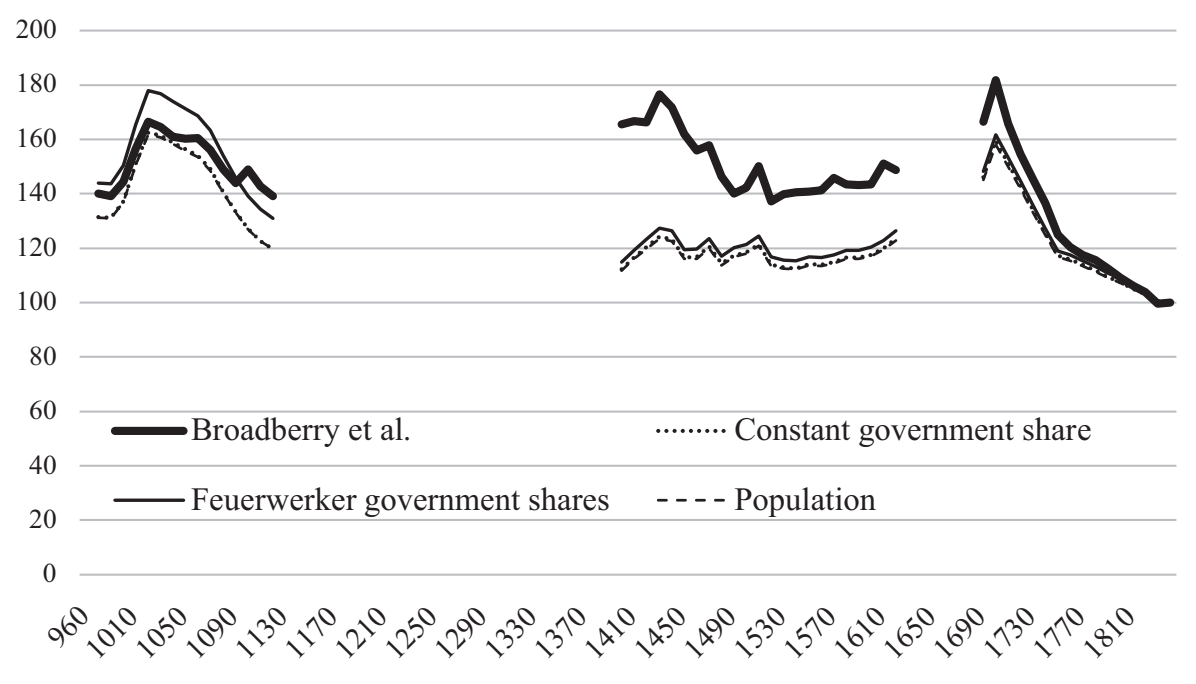

FIGURE 2

GDP PER CAPITA: ORIGINAL AND REVISED GOVERNMENT SECTOR

$(1840=100)$

Notes: The revised figures reflect the replacement of the original government sector series by three series created on different assumptions: (1) that the government share of GDP remained constant at its 1840 value throughout; (2) that the government share of GDP followed Feuerwerker's calculations: 13 percent during the Song; 7 percent during the Ming; 6 percent during the Qing; (3) that the government sector maintained a constant relationship with population.

Source: Broadberry, Guan, and Li (2018).

These changes restore the Song efflorescence to its prominent place in global history, whereas on BGL's estimates of per capita incomes, the Song peak had been equaled, if not slightly surpassed, in the early Ming. The revised estimates also show per capita incomes not to have changed very much during the Ming.

The revised estimates highlight a sharp peak in Chinese GDP per capita c. 1700 . Xu et al.'s $(2015,2017)$ estimates for GDP per capita begin in 1660 and fall from then onwards; in the early eighteenth century, at more or less the same pace as the revised BGL estimates. Their work suggests that the peak, sometime in the mid-seventeenth century, was even higher and the corresponding rise in per capita income from the Ming even larger. Real wage evidence, while not the same as GDP per capita, indicates that such a peak may have occurred in the 1660s: a sharp rise in real wages, amounting to an astonishing 150 percent, has been estimated to have taken place from the 1640 s to the 1660 s, though this was a particularly troubled period (de Zwart and van Zanden 2018, p. 218).

How do the revisions affect international comparisons? We will use our revised estimates to investigate this, but first, BGL's 1840 benchmark 
TABLE 1

GDP PER CAPITA LEVELS IN EUROPE AND ASIA (1990 International Dollars)

\begin{tabular}{lcccc}
\hline \hline & China & Italy & Netherlands & Great Britain \\
\hline 1020 & 902 & & & \\
1090 & 733 & & & 723 \\
1300 & & 1466 & & 724 \\
1400 & 600 & 1570 & 958 & 1045 \\
1500 & 637 & 1408 & 1141 & 1068 \\
1600 & 632 & 1224 & 1825 & 1077 \\
1700 & 874 & 1344 & 1849 & 1563 \\
1800 & 576 & 1327 & 1974 & 2080 \\
1850 & 535 & 1306 & 2397 & 2997 \\
\hline
\end{tabular}

Sources: China: Appendix Table 1; Italy, Netherlands, and Great Britain: Broadberry, Guan, and $\operatorname{Li}(2018)$.

for Chinese GDP per capita (599 1990 dollars) needs revision as well. Although they claim to have data for nominal GDP in 1840, their figures are based on the extrapolation, using only a series for grain output, of 1880s GDP back to 1840 , with the remaining sectors being estimated according to their shares in the 1880s. Other scholars have made more direct estimates of Chinese GDP back to the mid-nineteenth century. Xu et al. $(2015,2017)$ put GDP per capita in 1850 at 538 , also in 1990 dollars. Ma and de Jong (2019) come up with \$528 in 1840 and \$532 in 1850. The latter's annual estimates show GDP per capita to be essentially flat during the $1840 \mathrm{~s}$, so, taking the results of these alternative estimates together, Chinese GDP per capita in 1840 might be set at \$535, about 11 percent lower than BGL's figure.

Revised estimates for Chinese GDP per capita, on the assumption of a constant government share at its 1840 level, are shown, along with figures for Italy, the Netherlands, and Great Britain, in Table 1, an abbreviated version of BGL's Table 8. These show that levels of GDP per capita in the European leaders were well above those in China from at least 1400 when figures for all four countries are first available. But, as the California school has rightly insisted, the appropriate comparison is with China's leading region, the Yangzi delta. BGL (p. 990) take, as an upper bound, that per capita incomes in the delta were 75 percent higher than those for China as a whole. ${ }^{6}$ Adopting this assumption and

\footnotetext{
${ }^{6} \mathrm{Ma}(2008)$ estimates that per capita income in the Lower Yangzi was 55 percent higher than that of China in 1933 and cites figures showing that land tax revenue per capita in the area was 44 percent higher than the national average in the mid-eighteenth century.
} 


\section{China's GDP: Some Corrections and the Way Forward 949}

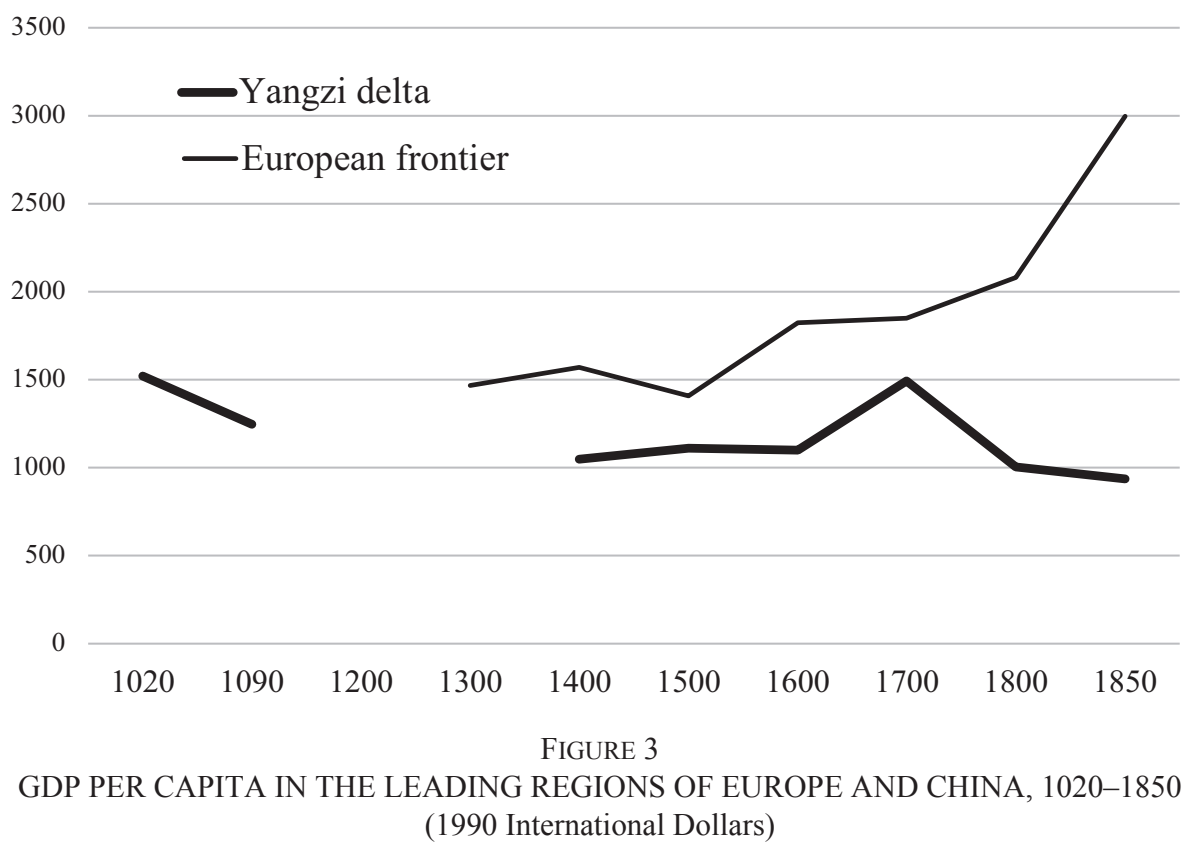

Notes: European frontier: maximum of Italy, Netherlands, and Great Britain; Yangzi Delta: 1.75 times China, which is the series constructed on the assumption that the government share remained constant at its 1840 value.

Source: Table 1.

comparing the Yangzi delta to the leading European country at each date produces Figure 3, a revised version of BGL's Figure 8.

The picture of development in China relative to Europe looks very different from that given by BGL. Their estimates showed per capita income levels in the Yangzi delta as more or less equivalent to those in the leading European countries from 1400 until 1700, after which there was a very sharp divergence. The revised figures show, by contrast, that during the Ming, per capita incomes in the delta were 20-40 percent lower than in the European leader, and these comparisons are based on BGL's upper bound estimates.

BGL do not make international comparisons before 1400 for want both of estimates before 1300 for Italy, the leading European country, and of estimates for China in 1300. But the high level of income per capita in the Song does suggest that there may have been a Great Crossing in the Middle Ages. As per capita incomes fell in China during the late Song and between the Song and the Ming, they probably rose in Italy, the leading European country. Trends in urbanization support this hypothesis. Malanima (2005) suggests that the urbanization rate in Italy at least doubled between 1000 and 1300. By contrast, Xu ,van Leeuwen, and van Zanden (2018) see the 
urbanization rate in the Yangzi delta falling from 25 to 18 percent during the thirteenth century, and this was a century or more after the Song peak in the eleventh century. A crossing in the Middle Ages is also consistent with trends in manuscript and book production which Buringh and van Zanden (2009) and Chaney (2018) have taken as indicators of development.

BGL's original estimates, and the revised estimates even more so, pose a major problem for the dating of the Great Divergence. According to the revised estimates, per capita incomes in the Ming were not much different from those in the mid-eighteenth century, but in the interim, there was a major peak in per capita income c.1700. As noted above, on Xu et al.'s (2017) estimates, this peak may have been even higher and situated somewhat earlier, in the second half of the seventeenth century. In the international comparisons the result is, to multiply the Greats, a Great Convergence in the seventeenth century, then a Greater Divergence during the eighteenth and early nineteenth centuries. Without this peak, a more gradual divergence between the Yangzi delta and the European leaders may have started as early as the fifteenth or sixteenth century. Was this peak real? Did per capita incomes rise by almost a quarter from the late Ming to the early Qing and reach a level comparable to that in the Song efflorescence?

The central feature of China's seventeenth-century history is the dynastic change from the Ming to the Qing, which was marked by famine and war. Figures cited for population losses, often covering different periods, are on the order of about a fifth (Marks 1998, p. 158; Myers and Wang 2002, pp. 565, 571; Shi 2020, p. 179). After the Black Death in Europe, the population decline led to an increase in the relative price of labor. In the mid-seventeenth century, Chinese rice prices doubled, but land prices remained largely unchanged, suggesting a similar change in relative prices (von Glahn 1996). This should have resulted in less intensive cultivation, which would not necessarily be captured when agricultural output is estimated only as grain yields times the entire cultivated area. The Chinese economy was also disrupted by a ban on maritime trade from 1661 to 1683 and continuing wars to consolidate the regime. The period from 1660 to 1690 has been described as the "Kangxi depression," which does not suggest a period in which per capita incomes were exceptionally high (von Glahn 2016). In the qualitative literature, at least in English, the subsequent decades are seen as a period of recovery, not as one of singular prosperity (Myers and Wang 2002; Rowe and Brook 2009; von Glahn 2016). Yet, on the revised estimates, when the Chinese population had recovered its late Ming level in the first decades of the eighteenth century, per capita incomes were $20-25$ percent higher. 


\section{China's GDP: Some Corrections and the Way Forward 951}

TABLE 2

CHINESE POPULATION LEVELS

(Million)

\begin{tabular}{|c|c|c|c|c|c|c|c|c|c|}
\hline & \multicolumn{2}{|c|}{ BGL } & \multicolumn{2}{|c|}{ Xu et al. } & \multicolumn{2}{|c|}{ Shi } & \multicolumn{2}{|c|}{ Cao } & Deng \\
\hline c 1100 & 115 & & & & & & 120 & & 115 \\
\hline c 1400 & 72 & & & & 65 & & 69 & & 67 \\
\hline c 1600 & 160 & & & & 150 & $0.41 \downarrow$ & & & 56 \\
\hline 1630 & & & & & & & 183 & $0.41 \downarrow$ & \\
\hline 1644 & & & & & & & 145 & & \\
\hline 1655 & & & & & & & & & 39 \\
\hline 1661 & & & 120 & & 120 & & & & 53 \\
\hline 1679 & & & & & & & 160 & & 47 \\
\hline 1685 & & & 146 & $0.83 \downarrow$ & 139 & $0.60 \downarrow$ & & & 56 \\
\hline 1700 & 138 & $-1,27 \uparrow$ & & & & & & & 56 \\
\hline 1720 & 178 & $-1,27 \uparrow$ & & & & & & & 70 \\
\hline 1725 & & & 202 & $0.83 \downarrow$ & 175 & $0.60 \downarrow$ & 200 & & 72 \\
\hline 1730 & 202 & $-1,27 \uparrow$ & & & & & & & \\
\hline 1750 & 260 & & & & & & & & \\
\hline 1760 & 274 & $0.55 \downarrow$ & & & & & & & \\
\hline 1766 & & & 286 & $0.83 \downarrow$ & 278 & $1.11 \downarrow$ & & & 208 \\
\hline 1770 & 290 & $0.55 \downarrow$ & & & & & & & \\
\hline 1776 & & & & & & & 311 & & \\
\hline
\end{tabular}

Notes: Shuo Chen kindly supplied me with the data from Cao. Numbers in italics are extrapolations or interpolations from the values in bold; arrows show the direction of extrapolation.

Sources: BGL: Broadberry, Guan, and Li (2018); Xu et al. (2017); Shi (2020); Cao (2000); Deng (2004).

This late seventeenth-century or early eighteenth-century peak might, at least in part, be due to BGL's figures for China's population in 1700 being too low. The seventeenth century is a notably uncertain period for estimates of population. Deng (2004) argues vigorously for sticking to the official counts, but most authors either adjust these counts upwards by at least twofold or they extrapolate forward from the late fourteenth century or backward from the late eighteenth century when population figures are regarded as somewhat more reliable. ${ }^{7}$ Table 2 and Figure 4 show various estimates for China's population in the seventeenth and eighteenth centuries, including indications of where extrapolations have

\footnotetext{
${ }^{7}$ Note that adopting Deng's unadjusted figures would increase the revised BGL estimates of Chinese GDP per capita during the seventeenth century by double or more, leaving China much richer than the European leaders until a divergence took place in the eighteenth century that would have been even more pronounced than that estimated by BGL. They would also imply a doubling of GDP per capita during the Ming.
} 


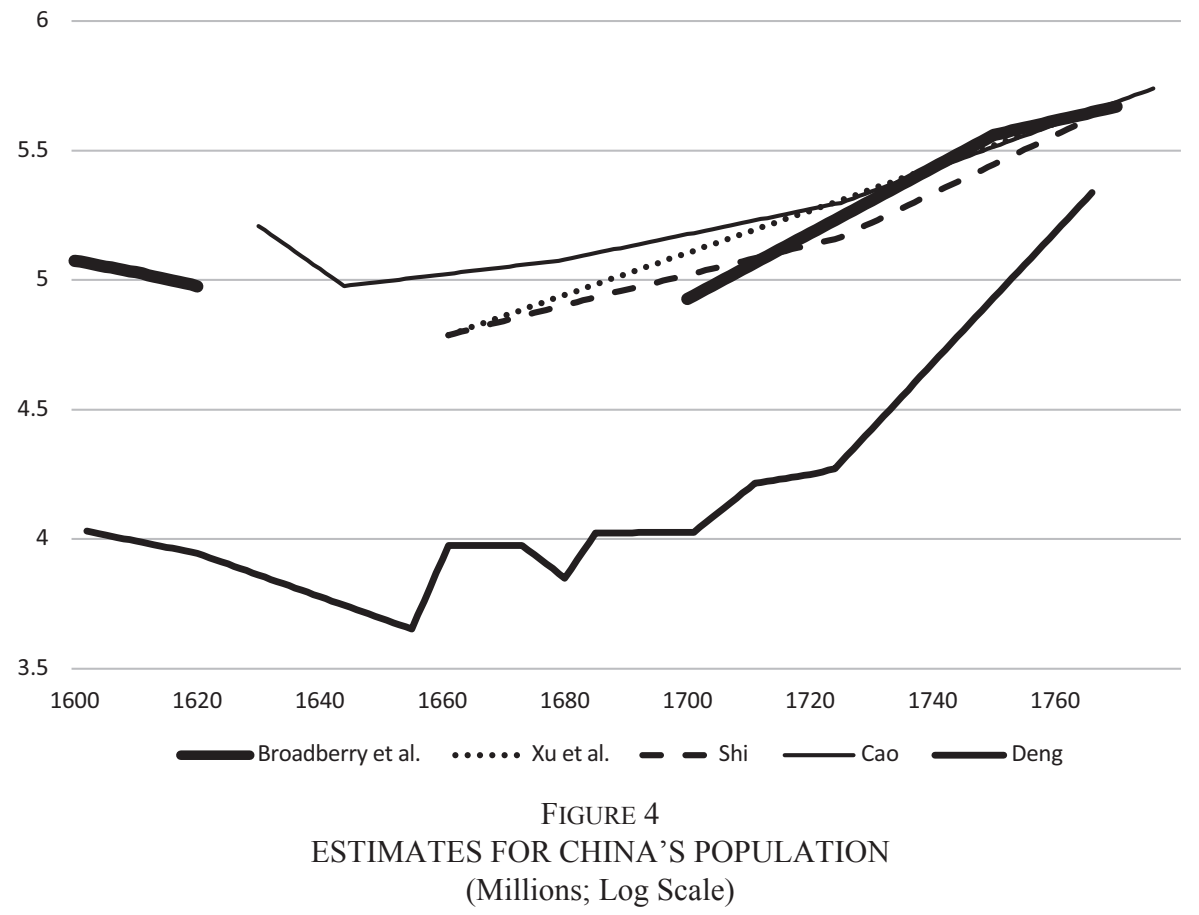

Source: See Table 2.

been made. Although BGL state that "there seems to be a high degree of consensus about the trend of China's population over this period" ( $p$. 964), when their estimate c. 1700 is compared with other recent work, it is clearly at the lower end, mainly because their extrapolation backward from 1750 has been made at a particularly steep rate, implying population growth at 1.27 percent per capita over the entire first half of the eighteenth century. Implicitly, BGL are assuming that population growth was slow in the second half of the seventeenth century, probably less than half a percent, before accelerating sharply around 1700 and subsequently decelerating, equally sharply, to 0.55 percent after 1750 . By contrast, $\mathrm{Xu}$ et al. (2017) assume that growth was constant over the late seventeenth and early eighteenth centuries, Shi (2020) that there was a modest acceleration from the 1720s and Cau (2000) that growth was accelerating throughout the period. This is hardly "a high degree of consensus." Adopting any of the higher estimates for the Chinese population c. 1700 would reduce the peak in Chinese GDP per capita shown in both BGL's original and revised estimates; using Cao's figure would eliminate it entirely, leaving per capita GDP at more or less the same level as in 1620.

All of these conclusions depend on the accuracy of BGL's estimates of Chinese GDP as revised. Even with a more plausible government sector, 


\section{China's GDP: Some Corrections and the Way Forward 953}

TABLE 3

WEIGHTS OF UNDERLYING SERIES IN THE GDP ESTIMATES, 1840

\begin{tabular}{|c|c|c|c|}
\hline Sector & $\begin{array}{c}\text { Sector } \\
\text { Share } \\
1840 \\
(\%)\end{array}$ & Evidence & $\begin{array}{c}\text { Evidence } \\
\text { Share } \\
(\%)\end{array}$ \\
\hline Grain crops & 48.78 & "Grain output" & 72.50 \\
\hline Cash crops & 12.29 & "Grain output" & \\
\hline Livestock, forestry, fishing & 5.07 & "Grain output" & \\
\hline Food processing & 0.59 & "Grain output" & \\
\hline Commerce industrial & 0.34 & "Grain output" & \\
\hline Commerce agricultural & 5.43 & "Grain output" & \\
\hline Textiles & 3.67 & Population & 6.89 \\
\hline Other manufacturing & 0.71 & Population & \\
\hline Commerce industrial & 2.51 & Population & \\
\hline Building & 1.18 & Pop., adjusted by urbanization & 12.89 \\
\hline Housing and other services & 11.70 & Pop., adjusted by urbanization & \\
\hline Government & 4.74 & Government expenditure & 4.74 \\
\hline Salt & 0.79 & Salt output & 2.50 \\
\hline Other metals & 0.80 & Salt output & \\
\hline Commerce industrial & 0.91 & Salt output & \\
\hline Iron & 0.14 & Iron output & 0.45 \\
\hline Other metals & 0.14 & Iron output & \\
\hline Commerce industrial & 0.16 & Iron output & \\
\hline Copper & 0.01 & Copper output & 0.03 \\
\hline Other metals & 0.01 & Copper output & \\
\hline Commerce industrial & 0.01 & Copper output & \\
\hline Total & 100.00 & & 100.00 \\
\hline
\end{tabular}

Notes: "Grain output" = total cultivated area $\mathrm{x}$ rice and wheat yields. Note that the figures for commerce, government, and housing and other private services in Broadberry, Guan, and Li's Table 2 are incorrect; they should be 503,932, 254,823, and 629,654, respectively.

Source: Broadberry, Guan, and Li (2018).

BGL's estimates for China's historical GDP can only be a first, relatively limited, sketch for a fuller picture of how the country's economy evolved in the past. Table 3 unravels how the various subsectors have been estimated, rearranging them to show how much the GDP estimates depend on each of the data series that underlies them. For example, the series for salt, iron, and copper outputs were first used to estimate the output of other metals and then, along with other industrial sectors, used to estimate the share of commercial services (transport, trade, and finance) relating to industrial output. "Grain output" (total cultivated area times cereal yield) stands in for the rest of commercial services, as well as for the food processing industry, agricultural output other than grain, and fishing and forestry. 
What is striking about Table 3 is that, ultimately, the estimates of Chinese GDP over the long term depend, for over 92 percent, on "grain output" and population, the latter sometimes adjusted by urbanization. ${ }^{8}$ Since most economies before the twentieth century were poor and predominantly agricultural, such heavy reliance on grain output might indeed be a first approximation to the size of the economy. But it may not always be a very good approximation. Consider the case of England, drawing on the data underlying Broadberry et al.'s (2015) estimates. Series for English agricultural output, calculated, as for China, as the yield of wheat times the entire cultivated area, and for English population move so much in synch that, no matter what the weighting scheme, estimates of English GDP per capita based on just these two series show it to have remained essentially constant over six centuries. By contrast, Broadberry et al.'s more sophisticated estimates show English GDP per capita to have tripled over this period, in part because of structural changes both within the agricultural sector and between it and the industrial and service sectors. ${ }^{9}$

Table 3 suggests that, as things stand, the top priority for historical national accounts should be to make sure that the series for population and "grain output" be as accurate as possible. Although Deng and O'Brien (2016) have cast doubt on the possibility of making sense of the multitude of land area measures in use, Shi (2020) has tried to do so. ${ }^{10}$ As noted previously, Deng (2004) has criticized the population figures, and Table 2 and Figure 4 show the uncertainties of extrapolation over even relatively short periods. Since agriculture was throughout the millennium the major sector of the Chinese economy, a second priority would be to understand how changes in specialization within that sector may have influenced overall output. "Grain output" has been put in quotations because agricultural output has been estimated by multiplying the total cultivated area by an amalgam of rice and wheat yields. How was the value of agricultural output influenced by increasing or decreasing

\footnotetext{
${ }^{8}$ Changes in urbanization make little difference since the four urbanization rates used by BGL, one each for the Song and Ming and two for the Qing, between which they interpolate, only vary between 5.2 and 6.8 percent. Recent estimates by Xu, van Leeuwen, and van Zanden (2018) show the urbanization rate varying between 7 and 12 percent and generally falling from the Song to the Qing, whereas BGL, relying on Rozman (1973), have urbanization at its peak during the early Qing.

${ }^{9}$ In the Chinese case, the results are quite similar. Over the entire period, 980 to 1840 , and based on BGL's figures, Chinese GDP per capita would have fallen by 8 percent if the weights on grain output and population were each 50 percent and by 17 percent if the weights on grain output were 80 percent and population 20 percent. These changes in per capita output are, as with those for England, again not greatly different from no change at all.

${ }^{10}$ But see the riposte by van Zanden and Ma (2017).
} 


\section{China's GDP: Some Corrections and the Way Forward 955}

cultivation of other crops, such as tea, silk, or cotton, all of which produced more value per area? Or by the introduction of new crops such as maize and sweet potatoes? A third priority would be better indicators of the movements in industrial output. As it stands, industrial output is essentially estimated from the level of population and the output of salt. ${ }^{11}$ What can be said about trends in important industries like silk, cotton, and ceramics? Qualitative evidence on new goods and services and specialization and trade, in the Chinese case mainly internal trade, are important for understanding potential biases in GDP estimates. Kelly (1997) has argued, for example, that the Song efflorescence was an example of Smithian growth as the development of a national waterway network led to the creation of a national market with increased regional specialization. Given the problems noted earlier with the government sector, a fourth priority would be better series for government expenditure or revenue. It may not be possible, indeed it is likely to be impossible to construct long quantitative series for all of these elements. Hence there is a need for historical national accountants to give users of their statistics a clear, albeit qualitative, idea of how and when their estimates may be overstating or understating changes in output.

\section{REFERENCES}

Bogart, Dan, Mauricio Drelichman, Oscar Gelderblom, and Jean-Laurent Rosenthal. "State and Private Institutions." In The Cambridge Economic History of Modern Europe, edited by Stephen Broadberry and Kevin H. O'Rourke, vol. 1, pp. 70-95. Cambridge: Cambridge University Press, 2010.

Broadberry, Stephen, Bruce Campbell, Alexander Klein, Mark Overton, and Bas van Leeuwen. British Economic Growth, 1270-1870. Cambridge: Cambridge University Press, 2015.

Broadberry, Stephen, Johann Custodis, and Bishnupriya Gupta. "India and the Great Divergence: An Anglo-Indian Comparison of GDP per Capita, 1600-1871." Explorations in Economic History 55 (2015): 58-75.

Broadberry, Stephen, Hanhui Guan, and David Daokui Li. "China, Europe, and the Great Divergence: A Study in Historical National Accounting, 980-1850.” Journal of Economic History 78, no. 4 (2018): 955-1000.

Buringh, Eltjo, and Jan Luiten van Zanden. "Charting the 'Rise of the West': Manuscripts and Printed Books in Europe, A Long-Term Perspective from the Sixth through Eighteenth Centuries." Journal of Economic History 69, no. 2 (2009): 409-44.

\footnotetext{
${ }^{11}$ The series for salt output has peculiar implications for per capita output: in the early Ming and the Qing, its level is roughly twice that in the Song and the late Ming (and in 1430 it is four times as high). Chiang (1976) makes a detailed comparison of salt production in the late fourteenth and the mid-nineteenth centuries and concludes that salt production and population increased by more or less the same percentage, which would make sense if most salt was used as a complement to grain consumption.
} 
Cao, S. J. Zhongguo Ren Kou Shi (History of Population in China). Shanghai: Fudan University Press, 2000.

Chaney, Eric. "Medieval Origins: A Review Essay on Campbell's The Great Transition." Journal of Economic Literature 56, no. 2 (2018): 643-56.

Chiang, Tao-Chang. "The Production of Salt in China, 1644-1911." Annals of the Association of American Geographers 66, no. 4 (1976): 516-30.

De Zwart, Pim, and Jan Luiten van Zanden. The Origins of Globalization: World Trade in the Making of the Global Economy, 1500-1800. Cambridge: Cambridge University Press, 2018.

Deng, Kent. "Unveiling China's True Population Statistics for the Pre-Modern Era with Official Census Data." Population Review 43, no. 2 (2004): 32-69.

. "The Continuation and Efficiency of the Chinese Fiscal State, 700 BCAD 1911." In The Rise of Fiscal States: A Global History, 1500-1914, edited by Bartolomé Yun-Casalilla and Patrick K. O’Brien, pp. 335-52. Cambridge: Cambridge University Press, 2012.

Deng, Kent, and Patrick K. O'Brien. “China's GDP Per Capita from the Han to Modern Times." World Economics 17 (2016): 79-123.

Feuerwerker, Albert. "The State and the Economy in Late Imperial China." Theory and Society 13, no. 3 (1984): 297-326.

Huang, Ray. Taxation and Government Finance in Sixteenth-Century Ming China. Cambridge: Cambridge University Press, 1975.

Kelly, Morgan. "The Dynamics of Smithian Growth." Quarterly Journal of Economics 112, no. 3 (1997): 939-64.

Ma, Debin. "Economic Growth in the Lower Yangzi Region of China in 1911-1937: A Quantitative and Historical Analysis." Journal of Economic History 68, no. 2 (2008): 355-92.

-. "State Capacity and Great Divergence, the Case of Qing China (1644-1911)." Eurasian Geography and Economics 54, nos. 5-6 (2013): 484-99.

Ma, Ye, and Herman de Jong. "Unfolding the Turbulent Century: A Reconstruction of China's Historical National Accounts, 1840-1912." Review of Income and Wealth 65, no. 1 (2019): 75-98.

Malanima, Paolo. "Urbanisation and the Italian Economy during the Last Millennium." European Review of Economic History 9, no. 1 (2005): 97-122.

Marks, Robert. Tigers, Rice, Silk, and Silt: Environment and Economy in Late Imperial South China. Cambridge: Cambridge University Press, 1998.

Myers, Ramon, and Yeh-chien Wang. "Economic Developments, 1644-1800.” In The Cambridge History of China, edited by Willard J. Peterson, vol. 9, part 1, pp. 563-645. Cambridge: Cambridge University Press, 2002.

Prados de la Escosura, Leandro. "European Patterns of Development in Historical Perspective." Scandinavian Economic History Review 55, no. 3 (2007): 187-221.

Robinson, David M. "Military Labor in China, c. 1500." In Fighting for a Living: A Comparative History of Military Labour, 1500-2000, edited by Erik-Jan Zürcher, pp. 43-80. Amsterdam: Amsterdam University Press, 2013.

Rosenthal, Jean-Laurent, and Bin Wong. Before and Beyond Divergence: The Politics of Economic Change in China and Europe. Cambridge, MA: Harvard University Press, 2011.

Rowe, William T., and Timothy Brook. China's Last Empire: The Great Qing. Cambridge, MA: Harvard University Press, 2009. 


\section{China's GDP: Some Corrections and the Way Forward 957}

Rozman, Gilbert. Urban Networks in Ch'ing China and Tokugawa Japan. Princeton: Princeton University Press, 1973.

Shi, Zhihong. Agricultural Development in Qing China: A Quantitative Study, 16611911. Leiden: Brill, 2020.

Solar, Peter M. “Estimating China's GDP, 980-1840.” Ann Arbor, MI: Inter-university Consortium for Political and Social Research [distributor], 2021-11-18. https://doi. org/10.3886/E126921V1.

Swope, Kenneth M. A Dragon's Head and a Serpent's Tail: Ming China and the First Great East Asian War, 1592-1598. Norman, OK: University of Oklahoma Press, 2009.

van Zanden, Jan Luiten, and Debin Ma. "What Makes Maddison Right: Chinese Historic Economic Data." World Economics 18, no. 3 (2017): 203-13.

von Glahn, Richard. "Myth and Reality of China's Seventeenth-Century Monetary Crisis." Journal of Economic History 56, no. 2 (1996): 429-54.

. The Economic History of China: From Antiquity to the Nineteenth Century. Cambridge: Cambridge University Press, 2016.

Wen-Chin, Hsu. "Social and Economic Factors in the Chinese Porcelain Industry in Jingdezhen during the Late Ming and Early Qing Period, ca. 1620-1683." Journal of the Royal Asiatic Society 120, no. 1 (1988): 135-59.

Wong, R. Bin. "Taxation and Good Governance in China, 1500-1914." In The Rise of Fiscal States: A Global History, edited by Bartolomé Yun-Casallia and Patrick K. O’Brien, pp. 353-77. Cambridge: Cambridge University Press, 2012.

$\mathrm{Xu}$, Yi, Shi Zhihong, Bas van Leeuwen, Yuping Ni, Zipeng Zhang, and Ye Ma. "Chinese National Income, ca. 1661-1933.” Munich Personal RePEc Archive Paper No. 70873, Munich, Germany, 2015.

- "Chinese National Income, ca. 1661-1933." Australian Economic History Review 57, no. 3 (2017): 368-93.

$\mathrm{Xu}, \mathrm{Yi}, \mathrm{Bas}$ van Leeuwen, and Jan Luiten van Zanden. "Urbanization in China, c.1100 1900." Frontiers of Economics in China 13, no. 3 (2018): 322-68. 